\title{
Antihepatotoxic Activity of Phyllanthus atropurpureus Cultivated in Egypt
}

\author{
Taha Sarg, Afaf Abdel Ghani, Rawia Zayed*, and May El-Sayed \\ Department of Pharmacognosy, Faculty of Pharmacy, Zagazig University, 44519 Zagazig, \\ Egypt. E-mail: rawiazayed@hotmail.com \\ * Author for correspondence and reprint requests \\ Z. Naturforsch. 66 c, 447-452 (2011); received April 27, 2010/June 10, 2011 \\ The genus Phyllanthus (family Euphorbiaceae) is considered one of the important medici- \\ nal and ornamental plants. A phytochemical analysis of the extracts was performed to search \\ for the active ingredient. Results of the investigation of the hepatoprotective activity of \\ Phyllanthus atropurpureus Boj. Hort. Maurit. revealed that the activities of alcoholic extracts \\ of its aerial parts and roots were quite similar to those of silymarin. Both of them improve \\ the parameters of $\mathrm{CCl}_{4}$-induced liver injury including serum aspartate aminotransferase and \\ alanine aminotransferase. Among the extracts tested, the root extract showed maximum \\ activity compared to the aerial parts extract and to silymarin.
}

Key words: Phyllanthus, Euphorbiaceae, Hepatoprotective Activity

\section{Introduction}

The liver is one of the largest glands and most complex organs in the body. It performs multiple functions, including the production of proteins and enzymes, detoxification, metabolic functions, the regulation of cholesterol and blood clotting (Marsano et al., 2003). It contains the highest concentration of enzymes involved in phase I oxidationreduction reactions (Guegenrich, 1994). It is the primary site of biotransformation and detoxification of exogenous toxic xenobiotics (Lee, 1995)

Unfortunately, the liver is often the most abused organ in the body. It is exposed to alcohol, drugs, and a multitude of environmental toxins. An overstressed liver can impair detoxification and manifest in what may appear to be unrelated symptoms. Eventually, a dysfunctional liver can not perform its tasks properly and, consequently, the body becomes subject to toxicity and an overall decline in metabolic function (Treadway, 1998).

Problems associated with liver dysfunction can ultimately lead to serious illness such as hepatitis, cirrhosis, fatty liver, alcoholic liver disease, and biliary cirrhosis (Scott, 1998). Cirrhosis is a complex disease in which several biological and biochemical alterations are combined, and no proven effective treatment capable of reversing it has been developed (Matsuda et al., 1995). Many plants demonstrate hepatoprotective activity. Some Phyllanthus plants were used as remedies against hepatic disorders (Hawkins, 2001; Harish and Shivanandappa, 2006; Pramyothin et al., 2007). Karuna et al. (2009) suggested that consumption of the non-toxic Phyllanthus amarus aqueous extract can be linked to an improved antioxidant status and reduction in the risk of oxidative stress. Ahmed et al. (2009) stated that the whole plant of Phyllanthus debilis afforded a new oxiranofuranocoumarin (debelalactone) which showed antihepatotoxic activity. Nworu et al. (2010) confirmed that the decoctions of Phyllanthus niruri are promoted in traditional medicine of Africa, Asia, and South America as beneficial supplement for different infectious diseases, especially for viral hepatitis and tumour, and for immune compromised patients.

Generally many Phyllanthus species contain many tannins, lignans, and flavonoids which possess antioxidant and hepatoprotective activity (Anila and Vijayalakshmi, 2003; Pramyothin et al., 2007; Singh et al., 2009). This stimulated the interest to study the ability of an ethanolic extract of Phyllanthus atropurpureus to repair rat liver damage induced by $\mathrm{CCl}_{4}$ and also the possible mechanisms of the hepatoprotection.

\section{Material and Methods \\ Experimental animals}

Fifty adult male albino rats weighing about $200-250 \mathrm{~g}$ were used in the present investigation. 
Table I. Groups of animals and treatments.

\begin{tabular}{lll}
\hline Group & Dose & Treatment \\
\hline $\begin{array}{l}\text { (1) } n=10, \\
\text { control group }\end{array}$ & $\begin{array}{l}30 \mu \mathrm{l} / 100 \mathrm{~g} \\
\text { body weight } \\
\text { (IP) }\end{array}$ & $\begin{array}{l}\text { Received liquid } \\
\text { paraffin for 45 days }\end{array}$ \\
$\begin{array}{l}\text { (2) } n=40, \\
\begin{array}{l}25 \mu \mathrm{l} / 100 \mathrm{~g} \\
\text { bobacute } \\
\text { cirrhotic }\end{array}\end{array}$ & $\begin{array}{l}\text { Received } \mathrm{CCl}_{4} \text { diluted } \\
\text { (IP) }\end{array}$ & $\begin{array}{l}\text { (1:6) with liquid } \\
\text { paraffin, three times } \\
\text { a week for 45 days }\end{array}$ \\
\hline
\end{tabular}

$n$, Number of animals; IP, intraperitoneal.

The animals were housed in cages with wood shaving bedding, and allowed to become acclimatized to laboratory conditions for one week before the experiment. The animals were randomly divided into two groups [(1) and (2); Table I]. Group (2) was subdivided into 4 subgroups [(A)-(D)] which are listed in Table II.

\section{Induction of liver cirrhosis}

Liver cirrhosis was induced in rats by intraperitoneal (IP) injection (Hernandez-Munoz et al., 1997) of $\mathrm{CCl}_{4} 3$ times a week for $45 \mathrm{~d}$ in a dose of $25 \mu \mathrm{l} / 100 \mathrm{~g}$ body weight. $\mathrm{CCl}_{4}$ was freshly diluted (1:6) in liquid paraffin directly before the injection.

\section{Blood sampling and serum preparation}

Blood samples were collected in clean dry test tubes from the orbital sinus of fasted rats using heparinized microcapillary tubes according to Riley (1960). Blood samples were centrifuged directly at $2000 \times \mathrm{g}$ for $15 \mathrm{~min}$ using a Labofuge 200 Heraeus Sepatech centrifuge. Liver enzymes (ALT, AST), proteins (total protein, albumin), and antioxidant parameters (malondialdehyde and glutathione) were determined in the collected plasma and serum.

\section{Determination of aspartate aminotransferase} (AST) and alanine aminotransferase (ALT)

The serum AST and ALT levels were determined by colorimetric methods (Rietman and Frankel, 1957) using diagnostic kits supplied by Plasmatek (Weil, Germany).

\section{Determination of total protein (Biuret method)}

Total protein was determined colorimetrically with biuret (Chromy and Fischer, 1977) using a diagnostic kit supplied by Biocon (Mönchberg, Germany).

\section{Determination of serum albumin}

Serum albumin was determined colorimetrically by the bromocresol green method (Doumas et al., 1971; Webester et al., 1992) using a diagnostic kit supplied by Biocon.

\section{Determination of malondialdehyde (MDA)}

MDA was identified as the product of lipid peroxidation that reacts with thiobarbituric acid in acidic medium at $95^{\circ} \mathrm{C}$ for $30 \mathrm{~min}$ to form a pink coloured compound absorbing at $534 \mathrm{~nm}$ (Ohkawa et al., 1979).

\section{Determination of reduced glutathione (GSH)}

GSH reduces 5,5'-dithio-bis-(2-nitrobenzoic acid) to produce a yellow compound which has an absorption maximum at $405 \mathrm{~nm}$ (Beutler et al., 1963).

\section{Plant materials}

Phyllanthus atropurpureus Boj. Hort. Maurit., family Euphorbiaceae (spurge), was collected in the flowering stage from plants cultivated in the medicinal plants garden of the Faculty of Science,

Table II. Drugs and chemicals used in the antihepatotoxic experiment. The subgroups received the drugs for 30 days (all drug solutions were freshly prepared just before use).

\begin{tabular}{llll}
\hline Subgroup & Drug name & Dose & Note \\
\hline (A) $n=10$ & & & Cirrhotic rats without treatment \\
(B) $n=10$ & Ethanolic aerial parts extract & $200 \mathrm{mg} / \mathrm{kg}$ (orally) & $\begin{array}{l}\text { The drugs were suspended or emulsified } \\
\text { in } 10 \% \text { gum }\end{array}$ \\
(C) $n=10$ & Ethanolic roots extract & $200 \mathrm{mg} / \mathrm{kg}$ (orally) & $\begin{array}{l}\text { The drugs were suspended or emulsified } \\
\text { in } 10 \% \text { gum }\end{array}$ \\
(D) $n=10$ & Silymarin & $100 \mathrm{mg} / \mathrm{kg}$ (orally) & The drug was dissolved in normal saline \\
\hline
\end{tabular}

$n$, Number of animals. 
Table III. Phytochemical screening of powdered P. atropurpureus.

\begin{tabular}{|c|c|c|c|c|c|c|c|c|}
\hline \multirow[t]{2}{*}{ Chemical test } & \multicolumn{2}{|c|}{ Petroleum ether } & \multicolumn{2}{|c|}{ Diethyl ether } & \multicolumn{2}{|c|}{ Chloroform } & \multicolumn{2}{|c|}{ Ethanol } \\
\hline & AP & $\mathrm{R}$ & $\mathrm{AP}$ & $\mathrm{R}$ & AP & $\mathrm{R}$ & AP & $\mathrm{R}$ \\
\hline For sterols and/or triterpenes & + & + & + & + & - & - & - & - \\
\hline For alkaloids & - & - & - & - & - & - & - & - \\
\hline For flavonoids & - & - & - & - & + & + & + & + \\
\hline For glycosides & - & - & - & - & - & - & + & + \\
\hline For tannins & - & - & - & - & - & - & + & + \\
\hline
\end{tabular}

AP, aerial parts; R, roots; +, detected; -, not detected.

Ain Shams University, Cairo, Egypt. The identification of the plant was kindly verified by Dr. Hesham Abd El-Aal Elshamy, Professor of Medicinal, Aromatic and Ornamental Plants, Horticulture Department, Faculty of Agriculture, Zagazig University, Zagazig, Egypt. A voucher specimen is deposited at the Department of Pharmacognosy, Faculty of Pharmacy, Zagazig University, Zagazig, Egypt. The plant material was shade-dried and ground by an electric mill to a moderately fine powder.

The air-dried and separately powdered aerial parts and roots of Phyllanthus atropurpureus were successively extracted till exhaustion in a Soxhlet apparatus with the following solvents: petroleum ether, diethyl ether, chloroform, and ethanol (95\%), applying one after the other. The extracts were collected separately, and the column of the Soxhlet apparatus was washed with $200 \mathrm{ml}$ of water and $100 \mathrm{ml}$ of a similar solvent as an eluent after each type of solvent extraction procedure. The eluted materials and each of the extracts were concentrated at $40{ }^{\circ} \mathrm{C}$ to $100 \mathrm{ml}$ in a rotary evaporator. Then each of the extracts was filtered, solvents were evaporated, and the solid residues were weighed and then investigated.

\section{Statistical analysis}

All results are expressed as mean \pm standard error of the mean (S.E.M). ANOVA and post ANOVA test at $p>0.05$ were used to test the significance of the differences between control and treated groups.

\section{Results}

\section{Phytochemical investigation}

From the preliminary chemical tests it could be suggested that the most bioactive compounds detected in Phyllanthus atropurpureus Boj. Hort.
Maurit. are flavonoids, isoflavonoids, tannins, and glycosides, as listed in Table III.

\section{Hepatoprotective activity}

As shown in Table IV, a reduction of the hepatic GSH level was observed in rats administered with $\mathrm{CCl}_{4}$. However, treatment with $P$. atropurpureus root extracts at a dose of $200 \mathrm{mg} /$ $\mathrm{kg}$ body weight exhibited a significant increase in the plasma levels of GSH. A significant increase in MDA levels was observed in $\mathrm{CCl}_{4}$-treated rats. However, treatment with $P$. atropurpureus extracts (root and aerial parts) at a dose of $200 \mathrm{mg} /$ $\mathrm{kg}$ body weight reduced significantly the MDA level elevated by $\mathrm{CCl}_{4}$ treatment; also in silymarin-treated rats, MDA levels were significantly reduced. The antioxidant activity of extracts of $P$. atropurpureus was comparable to that of silymarin, the reference hepatoprotective drug.

The results presented in Table IV demonstrate that the activities of serum AST and ALT (marker enzymes for liver damage) were significantly elevated in $\mathrm{CCl}_{4}$-treated animals compared to control rats indicating liver damage due to cytolysis resulting in higher levels of serum AST. The administration of silymarin at a dose of $100 \mathrm{mg} /$ $\mathrm{kg}$ body weight caused a significant reduction in ALT and AST levels which was quite similar to the significant reduction caused by oral administration of $P$. atropurpureus extracts at a dose of $200 \mathrm{mg} / \mathrm{kg}$ body weight in $\mathrm{CCl}_{4}$-intoxicated rats.

As listed in Table IV, only oral treatment of cirrhotic rats with the ethanolic extract of roots showed a significant elevation in the albumin level, while neither root extract nor aerial part extract produced any significant change in the total protein level.

These results indicate that the hepatoprotective activity of $P$. atropurpureus extracts is quite similar to that of silymarin. Both of them improve the 
parameters of $\mathrm{CCl}_{4}$-induced liver injury including serum AST and ALT. Among the extracts tested, the root extract showed maximum activity, as shown in Table IV, compared with the aerial parts extract relative to silymarin.

\section{Discussion and Conclusion}

\section{Antioxidant activity}

The extract of $P$. atropurpureus showed good antioxidant potential and prevented oxidation of proteins and lipids. By virtue of its ability to scavenge reactive oxygen species (ROS), it probably can modulate transcription factors and regulate the levels of antioxidant enzymes. Potent antioxidant activities in aerial parts of Phyllanthus may be due to the presence of phenolic and polyphenolic compounds, such as flavonoids (Agarwal and Tiwari, 1991), catechin (Deckar, 1995) and hydrolysable tannins, with geraniin being the most abundant (Foo, 1993, 1995; Foo and Wong, 1992), ellagic acid (Ishimaru et al., 1991), and lignans (Singh et al., 2009; Satynarayana et al., 1988).

Polyphenolic compounds enhance the stability of low-density lipoprotein (LDL) to oxidation by scavenging the superoxide anion (Robak and Gryglewski, 1988), singlet oxygen (Husain et al., 1987), and lipid peroxy radicals (Torel et al., 1986) and stabilizing free radicals involved in oxidative processes through hydrogenation or complex formation with oxidizing species (Lewis, 1993; Shahidi and Wanasusdara, 1992). La Casa et al. (2000) reported that rutin, a natural flavonol glycoside, induced a significant increase in the GSH activity. Flavonoids can reduce macrophage oxidative stress by inhibition of cellular oxygenases, such as NADPH oxidase, or by activating cellular antioxidants, such as GSH (Fuhrman and Aviram, 2001).

The potent antiperoxidative effect of Phyllanthus protects the liver by preventing trichloromethyl free radical $\left(\mathrm{CCl}_{3}{ }^{\circ}\right)$-induced peroxidative disintegration of membranes (Dhuley and Naik, 1997). The enhancement in the hepatic GSH status was associated with corresponding decreases in MDA levels and ALT activities, indicating a significant reduction in the extent of oxidative hepatocellular damage. In conclusion, the extracts of $P$. atropurpureus act as antioxidant and the anti-lipid peroxidation activity of the root extract was found to be higher than that of the aerial part extract that may be attributed to the presence of 
tannins in the root as reported previously (Bhattachary et al., 1999).

\section{Hepatoprotective activity}

The increased cytolysis, as is evident from the higher levels of serum AST, suggests that the enhanced microsomal lipid peroxidation in the liver is associated with a damage of hepatic tissue, which is in agreement with earlier findings (Barber, 1963). Carbon tetrachloride $\left(\mathrm{CCl}_{4}\right)$ is a hepatotoxic agent causing centrolobular necrosis and is associated with fatty liver. $\mathrm{CCl}_{4}$ is converted to the $\mathrm{CCl}_{3}{ }^{\cdot}$ radicle by hepatic mixed function oxidases. $\mathrm{CCl}_{3}{ }^{\circ}$ can abstract hydrogen from polyunsaturated fatty acids to initiate lipid peroxidation; alternatively in the presence of oxygen, it forms the more reactive trichloro-methylperoxy free radical $\left(\mathrm{CCl}_{3} \mathrm{COO}^{*}\right)$. $\mathrm{CCl}_{3} \mathrm{COO}^{\circ}$ can participate in lipid peroxidation or can decompose to phosgene $\left(\mathrm{CCl}_{2} \mathrm{O}\right)$ (Brattin et al., 1985).

Antioxidants and radical scavengers have been used to study the mechanism of $\mathrm{CCl}_{4}$ toxicity as well as to protect liver cells from $\mathrm{CCl}_{4}$-induced damage by breaking the chain reaction of lipid peroxidation. Silymarin has been reported to protect liver cells from a wide variety of toxins (Muriel and Mourelle, 1990; Bosisio et al., 1992), including $\mathrm{CCl}_{4}$. The hepatoprotective mechanism of silymarin may be due to its antioxidant activ-

Agarwal T. and Tiwari J. (1991), Note on the flavonoids and other constituents of Phyllanthus genus. J. Indian Chem. Soc. 68, 479-480.

Ahmed B., Khan S., Verma A., and Habibullah (2009), Antihepatotoxic activity of debelalactone, a new oxirano-furanocoumarin from Phyllanthus debilis. J. Asian Nat. Prod. Res. 11, 687-692.

Anila L. and Vijayalakshmi N. R. (2003), Antioxidant action of flavonoids from Mangifera indica and Emblica officinalis in hypercholesterolemic rats. Food Chem. 83, 569-574.

Barber A. A. (1963), Addendum mechanisms of lipid peroxide formation in rat tissue homogenates. Rad. Res. 3, 33-43.

Basage H., Poli G., and Tekkaya C. (1997), Free radical scavenging and anti-oxidation properties of "silibin" complexes on microsomal lipid per-oxidation. Cell. Biochem. Funct. 15, 27-33.

Beutler E., Duron O., and Kelly M. B. (1963), Improved method for the determination of blood glutathione. J. Lab. Clin. Med. 61, 882-888.

Bhattachary A., Chatterjee A., Ghosal S., and Bhattachyra S. K. (1999), Antioxidant activity of active tan- ity and/or inhibition of lipid peroxidation (Pietrangelo et al., 1995; Basage et al., 1997).

The pronounced hepatoprotective activity (compared to silymarin) of the ethanolic extract of $P$. atropurpureus found in this study is in agreement with that reported on the effect of other Phyllanthus species against various chemical liver toxins (Liu and Meintosh, 2001; Wang et al., 2001; Khatoon et al., 2006; Kumaran and Karunnakaran, 2007; Narayan et al., 2008; Syamasunder et al., 1985).

It can be concluded that the antioxidant property of ethanolic extracts of root and aerial parts of $P$. atropurpureus could counteract $\mathrm{CCl}_{4}$ toxicity. The hepatoprotective activity of $P$. atropurpureus may be due to the presence of polyphenolic compounds. Therefore, the hepatoprotective mechanism of Phyllanthus may involve its antioxidant activity against production of ROS. Thus, $P$. atropurpureus can be considered a new efficient hepatoprotective candidate, but clinical follow-up studies are needed to test the safe use in the whole organism.

\section{Acknowledgement}

The authors would like to express their deep feelings of gratitude to Prof. Dr. Ahmed Fahmy, Professor of Pharmacology, and Shimaa El-Shazly, Lecturer of Pharmacology, Faculty of Pharmacy, Zagazig University, Zagazig, Egypt, for carrying out the pharmacological screening.

noid principles of Emblica officinalis (amla). Indian J. Exp. Biol. 37, 676-680.

Bosisio E., Benelli C., and Pirola O. (1992), Effect of the flavanolignans of Silybbum marianum L. on lipid peroxidation in rat liver microsomes and freshly isolated hepatocytes. Pharmacol. Res. 25, 147-154.

Brattin W. J., Glende E. A., and Recknagel R. O. (1985), Pathological mechanisms in carbon tetrachloride hepatotoxicity. J. Free Radic. Biol. Med. 1, 27-38.

Chromy V. and Fischer J. (1977), Photometric determination of total protein in lipemic sera. Clin. Chem. 23, 754-756.

Deckar E. A. (1995), The role of phenolic, conjugated linoleic acid, carnosine and pyrrolquinolinequinone as nonessential dietary antioxidants. Nut. Rev. 53, 49-58.

Dhuley J. N. and Naik S. R. (1997), Protective effect of Rhinax, a herbal formulation, against $\mathrm{CCl}_{4}$-induced liver injury and survival in rats. J. Ethnopharmacol. 56, $159-164$.

Doumas B. T., Waston W. A., and Bigg H. G. (1971), Albumin standards and the measurement of serum albumin with bromcresol green. Clin. Chim. Acta 31, 87-96. 
Foo L. Y. (1993), Amariin, a di-hydrohexahydroxydiphenoyl hydrolysable tannin from Phyllanthus amarus. Phytochemistry 33, 487-491.

Foo L. Y. (1995), Amarinic acid and related ellagitannins from Phyllanthus amarus. Phytochemistry 39, 217-224.

Foo L. Y. and Wong H. (1992), Phyllanthusiin D, an unusual hydrolysable tannin from Phyllanthus amarus. Phytochemistry 31, 711-713.

Fuhrman B. and Aviram M. (2001), Flavonoids protect LDL from oxidation and attenuate atherosclerosis. Curr. Opin. Lipidol. 12, 41-48.

Guegenrich F. P. (1994), Catalytic selectivity of human cytochrome P450 enzymes: Relevance to drug metabolism and toxicity. Toxicol. Lett. 70, 133-138.

Harish R. and Shivanandappa T. (2006), Antioxidant activity and hepatoprotective potential of Phyllanthus niruri. Food Chem. 95, 180-185.

Hawkins E. B. (2001), From tradition to modernity: Asian therapies for cancer. J. Am. Bot. Coun. 53, 64-69.

Hernandez-Munoz R., Diaz- Munoz M., Lopez V., Yanez L., Vidro S., and De-Sanchez V. C. (1997), Balance between oxidative damage and proliferative potential in an experimental rat model of $\mathrm{CCl}_{4}$-induced cirrhosis: Protective role of adenosine administration. Hepatology 26,1100-1110.

Husain S. R., Cillard J., and Cillard P. (1987), Hydroxyl radical scavenging activity of flavonoids. Phytochemistry 26, 2489-2491.

Ishimaru K., Yoshimatsu K., Kamada H., and Shimomura K. (1991), Phenolic constituents in tissues cultures of Phyllanthus niruri. Phytochemistry 31, 2015-2018.

Karuna R., Reddy S. S., Baskar R., and Saralakumari D. (2009), Antioxidant potential of aqueous extract of Phyllanthus amarus in rats. Indian J. Pharmacol. 41, 64-67.

Khatoon S., Rai V., Rawat A., and Mehrotra S. (2006), Comparative pharmacognostical studies of three Phyllanthus species. J. Ethnopharmacol. 104, 79-86.

Kumaran A. and Karunnakaran J. (2007), In vitro antioxidant activities of methanol extracts of Phyllanthus species from India. LWR-Swiss Soc. Food Sc. Technol. 40, 344-352.

La Casa C., Villegas I., Alarcon-de-la-Lastra C., Motilva V., and Martin Calero M. J. (2000), Evidence for protective and antioxidant properties of rutin, a natural flavone against ethanol induced gastric lesion. J. Ethnopharmacol. 71, 45-53.

Lee W. M. (1995), Drug induced hepatotoxicity. N. Engl. J. Med. 333, 1118-1127.

Lewis N. G. (1993), Antioxidant in higher plants. In: Plant Phenolics (Alscher R. G. and Hess J. L., eds.). CRC Press, Boca Raton, pp. 135-169.

Liu J. H. and Meintosh H. (2001), Genus Phyllanthus for chronic hepatitis B virus infection: a systematic review. Viral. Hepatol. 8, 358-366.

Marsano L. S., Mendez C., Hill D., Barve S., and McClain C. (2003), Diagnosis and treatment of alcoholic liver diseases and its complications. Alcohol Res. Health 27, 247-256.

Matsuda Y., Matsumoto K., and Ichida T. (1995), Hepatocyte growth factor suppresses the onset of liver cirrhosis and abrogates lethal hepatic dysfunction in rats. J. Biochem. 118, 643-649.
Muriel P. and Mourelle M. (1990), Prevention by silymarin of membrane alterations in acute $\mathrm{CCl}_{4}$ liver damage. J. Appl. Toxicol. 10, 275-279.

Narayan Y., Anirban P., Karuna S., Dyaneshwar B., Anil G., Mahendra D., and Suman K. (2008), Synergistic effect of silymarin and standardized extract of Phyllanthus amarus against $\mathrm{CCl}_{4}$-induced hepatotoxicity in Rattus norvegicus. Phytomedicine 15, 1053-1061.

Nworu C. S., Akah P. A., Okoye F. B., and Esimone C. O. (2010), Aqueous extract of Phyllanthus niruri (Euphorbiaceae) enhances the phenotypic and functional maturation of bone marrow-derived dendritic cells and their antigen-presentation function. Immunopharmacol. Immunotoxicol. 32, 393-401.

Ohkawa H., Ohishi W., and Yagi K. (1979), Assay for lipid peroxides in animal tissues by thiobarbituric acid reaction. Anal. Biochem. 95, 351-358.

Pietrangelo A., Borella F., and Casalgrandi G. (1995), Anti-oxidant activity of silybin in vivo during longterm iron overload in rats. Gastroenterology 109, $1941-1949$.

Pramyothin P., Ngamtin C., Poungshompoo S., and Chaichantipyuth C. (2007), Hepatoprotective activity of Phyllanthus amarus Schum. et Thonn. extract in ethanol treated rats: In vitro and in vivo studies. J. Ethnopharmacol. 114, 169-173.

Rietman S. and Frankel S. (1957), A colorimetric method for determination of serum glutamic oxalacetic and glutamic pyruvic transaminases. Am. J. Clin. Pathol. 28, 56-63.

Riley V. (1960), Adaptation of orbital bleeding technique to rapid serial blood studies. In: Animal Models in Toxicology (Grad S. C. and Chengelis C. P., eds.). Marcel Dekker, New York, pp. 21-164.

Robak J. and Gryglewski J. (1988), Flavonoids are scavengers of superoxide anions. Biochem. Pharmacol. 37, $837-841$.

Satynarayana P., Subrahmanyan P., Viswanthan K., and Ward R. (1988), New seco and hydroxyl lignans from Phyllanthus niruri. J. Nat. Prod. 51, 44-49.

Shahidi F. and Wanasusdara D. (1992), Phenolic antioxidants. Crit. Rev. Food Sci. Nutr. 32, 67-103.

Singh M., Tiwari N., Shanker K., Verma K., Gupta K., and Gupta M. (2009), Two new lignans from Phyllanthus amarus. J. Asian Nat. Prod. Res. 11, 562-568.

Syamasunder V., Singh B., Thakur S., Husain A., and Hikino H. (1985), Anti-hepatotoxic principles of Phyllanthus niruri herbs. J. Ethnopharmacol. 14, 41-44.

Torel J., Cillard J., and Cillard P. (1986), Antioxidant activity of flavonoids and reactivity with peroxy radical. Phytochemistry 25, 383-385.

Treadway S. (1998), An ayurvedic herbal approach to a healthy liver. Clin. Nutr. Insights 6, 1-16.

Webester D., Bignell H., and Birkmayer J. (1992), An assessment of the suitability of bromcresol green for the determination of serum albumin. Clin. Chim. Acta 53, 101-108.

Wang X.-h., Li C.-q., Guo X.-b., and Fu L.-c. (2001), A comparative study of Phyllanthus amarus compound and interferon in the treatment of chronic viral hepatitis B. Southeast Asian J. Trop. Med. Public Health 32, $40-42$. 